\title{
Technology Leadership and Its Relationship with School-Malaysia Standard of Education Quality (School-MSEQ)
}

\author{
Mohd Izham Mohd Hamzah ${ }^{1}$, Faridah Juraime ${ }^{2}$, Aida Hanim A. Hamid ${ }^{1}$, Norazah Nordin ${ }^{1} \&$ Noraini Attan ${ }^{1}$ \\ ${ }^{1}$ Faculty of Education, Universiti Kebangsaan Malaysia, Malaysia \\ ${ }^{2}$ Malaysia Ministry of Education, Putrajaya, Malaysia, Malaysia \\ Correspondence: Mohd Izham Mohd Hamzah, Faculty of Education, Universiti Kebangsaan Malaysia, 43600 \\ UKM Bangi, Selangor, Malaysia. Tel: 601-9396-9737. E-mail: izham@ukm.edu.my
}

\author{
Received: October 30, 2014 Accepted: December 10, 2014 Online Published: December 22, 2014 \\ doi:10.5539/ies.v7n13p278 URL: http://dx.doi.org/10.5539/ies.v7n13p278
}

\begin{abstract}
This study examined the level of technology leadership practice among administrators in High Performing Schools (HPS) and its relationship with School-Malaysia Standard of Education Quality (School-MSEQ). A set of questionnaires was administered to 96 administrators in 12 HPS of secondary schools category. The data were analysed and interpreted using SPSS version 16.0. The statistics used were descriptive statistics and inferential statistics. Analysis of t-test, one way ANOVA and Pearson Correlation were used to test the hypotheses. This study found that the level of technology leadership practice was moderate with mean value at 3.934 and the practice of School-MSEQ among administrators was high with mean value at 4.729 . There was no significant difference from the aspects of administration experiences and status pose of HPS administrators in term of the practice of technology leadership. This study revealed a relationship between technology leadership and School-MSEQ $(r=0.649, \mathrm{p}<0.05)$ towards the practice of technology leadership among HPS administrators. The findings suggest that school administrators should play key roles in promoting technology in schools. It is hoped that the findings will improve the practice of school administrators and more studies should be conducted in the near future towards the improvement of technology leadership in schools.
\end{abstract}

Keywords: technology leadership, high performing schools, administrators, school-Malaysia standard of education quality

\section{Introduction}

The advancement of technology in the $21^{\text {st }}$ century demands change and improvement for quality education in most schools all over the world (Davies, 2010). Malaysia today is awarded as one of the countries that are successful in providing education access to all citizens. UNESCO in the Education for All Global Monitoring Report 2009 has ranked Malaysia at number 45 from 129 countries, thus, putting Malaysia among 56 countries at high level of Educational Development Index to all. This is a great success to educational institutions in Malaysia (Muhyiddin, 2009). Although Malaysia was placed at good rankings in the index of education for all, this does not mean that we could just feel comfortable with the achievement. In the effort of developing the country at high level, we must try not only to improve the access to education but also to widen the access to quality education.

The Prime Minister of Malaysia has listed the access to quality and affordable education as one of the six National Key Result Areas (NKRA) in effort to produce more competitive human capitals that could drive the high-income economy. The introduction of educational NKRA is one of the transformation process and education system renewal that is hoped could contribute to education excellence in this country. One of the components in NKRA is to create High Performing School (HPS).

The transformational process in providing a quality education system should be strengthen with the development of Information and Communication Technology (ICT) era. More improvement in various aspects should be done in order to become more competitive and relevant to the current needs. Therefore, excellent, effective and knowledgeable school leadership is important in determining the use of technology in school management system and the implementation of teaching and learning.

The change and development of ICT in education system of today could give advantages in assisting the 
education managers such as school administrators in making decisions, adapting to school change and increasing the communication in organization. Thus, the knowledge in ICT is very useful in seeking solutions to best, accurate and comprehensive decision-makings among administrators. Rashid (2007) stated that managers or school administrators could not stay apart from making decisions every day because it is one of important elements in school administrations and management.

Finally, the leadership and leadership process have formed various theories and models, which could be used towards achieving the organizational excellence, and the latest in research field is a model associated with technology leadership. Avolio (2000) described technology leadership as a relationship between leadership and technology. Leaders should play proactive roles in implementing technology and put extra efforts in the interface of information technologies components and human.

\subsection{Technology Leadership}

Administrators today have roles that are more challenging in this era of globalisation and technology explosion for the past two decades. The challenge to overcome the issues in this era seeks progressive change from the aspect of leadership and management of school administrators. Anderson and Dexter (2005) affirmed that the leadership of a principal is a key influence to the effectiveness of the school. Bilig et al. (2005) stated that in order to determine the factors that influence the sustainability of change such as technology change; it is found that leadership in an organisation is the main determination factor. In order to realize the change in education, it is undeniable that leadership influences the technology change at this moment. Thus, educational managers should emphasize ICT as an important variable in creating high performance management system.

Furthermore, Chang (2005) stated that the main responsibility of technology leader is to identify the relationship of technology, vision and school mission as well as education policy. In other words, the school administrators should understand the importance of ICT integration for students and provide conducive environment for students to learn. Furthermore, school administrator should empower the middle leaders; to promote the use of ICT among middle managers and to collaborate with experts and external organization in order to get support in the form of technology networking facility. The administrators should also play their roles as technology leader in order to create a learning culture in the school.

Therefore, the technology leadership seeks administrators to change the existing practice and to be more open towards the possibility of transformation to the leadership skill, knowledge and the tendency of traditional school management. In facing the challenge of ICT change, the mission of administrators as technology leaders is to form and implement new strategies in assisting teachers to identify, understand and integrate the technology of teaching and learning (Creighton, 2003). ISTE (2002) further stated that principals have specific roles in implementing the integration of ICT in teaching and learning of students and henceforth to achieve the education goals. The six dimensions identified are to identify the school mission, to manage the curriculum and teachings, to manage the productivity and professional practice, to support the management and operations, to conduct assessment and evaluation as well as to determine the issues related to social, legal and ethical.

Finally, Baharom et al. (2007) state that to ensure the ICT management system to work well as planned, the ICT management should have vast knowledge of ICT. They have to explore more knowledge through reading, trainings, surfing the internet or by conducting research. It is fair if all the members in the ICT management are well exposed to knowledge that is more complex. Meanwhile, the knowledge obtained could be used in order to increase the quality of ICT management system and the knowledge must be disseminated with other individuals for self-benefits and others and finally the benefits of the organisations.

\subsection{The School-Malaysia Standard of Education Quality}

The School-MSEQ is a system that originates from the National Education Philosophy. It emphasizes on the development of holistic individual potential for excellence. The School-MSEQ enables each school to examine and evaluate their own abilities in order to optimum the strength and to improve on the weaknesses (Mohd Salleh, 2002). The achievement of the school standard is based on the School Self Evaluation by using the Instrument Standard Objectivity of School-MSEQ, which describes twelve elements, and it could be categorized into four main dimensions. The weight age of school achievement is based on Leadership Direction (10\%), Organisation Management (30\%), Management of Education Programme (45\%) and Student Outcomes (15\%).

At school management level, the committee of School-MSEQ are principal as chairman, Senior Assistant Teacher I as Secretary I, Secretary II-Senior Assistant of Co-Curriculum, Secretary III-Senior Assistant of Student Affairs and committee members of Head of Panitia, Head of Unit (Co-curriculum) and Head of Unit (Student Affairs). The principals must plan, manage, implement and monitor as well as review the process of 
implementation of school progress plan during the schooling terms according to the working process, working flow chart, implementation duration and actions.

Therefore, all administrators should play their leadership roles as role model in encouraging the teachers to increase their work quality and bring the school towards effective school and towards the high performance, which serve as symbol and pride of local community. The efforts of increasing the quality of the schools are very important because one of the main issues which are continuously discussed by educators and society is the competitive and quality education. This is because the reformation does not focus on the formation of standard or comprehensive management standard in order to achieve the organisational goals (Zaharah, 2004). The achievement of organisational goals for excellence could be observed in one domain involving one continuum between the process of management and school administration. As a result, school administrators need a set of criteria that could be used to guide them in achieving the organisation goals through quality management system.

The instrument of School-MSEQ is used to assess the ability and potential of school administrator, leadership, management, the implementation of teaching and learning process, management of resource and nurturing the student outcomes. This School-MSEQ intends to assure the standard and self-rating evaluation made by the school itself and monitored by school inspectors, State Educational Department and District Education Office. The inspection methodology requires head teachers and principals to play their roles as instructional leader and main supervisor of teaching and learning in school. The statement of standard consists of twelve elements, which are categorized into four dimensions: Leadership Direction, Organisational Management, Management of Educational Programmes and Student Outcomes. Head teachers, Principals, and those related to the management of schools should be responsible to ensure all the listed elements are practiced in the school.

\subsection{Research Hypotheses}

Ho1: There is no significant difference of technology leadership practice among administrators in HPS in term of administration experience.

Ho There is no significant difference of technology leadership practice among administrators in HPS in term of status position held.

Ho 3: There is no significant relationship between the practice of technology leadership and the School-Malaysia Standard Education Quality in High Performance School.

\section{Method}

This is a quantitative study, which used survey research design. In obtaining standardized data, researcher used questionnaires method in data collection. This study used the approach of Model Technology Leadership proposed by Anderson and Dexter (2005) and National Educational Technology Standard for Administrators (NETS-A, 2002) which was proposed by ISTE (2000). It consists of six dimensions: vision and leadership, teaching and learning, professionalism practice and productivity, management support and operation, testing and evaluation; and issues of ethics, social and legal. The chosen model and standard are aligned with the purpose of research in obtaining knowledge on the level of technology practice among administrators in High Performing School and examine the difference of level of practice in term of demographic factors such as administration experience and status of position held. Next, this study also investigates the approach of School-Malaysia Standard Education Quality (School-MSEQ) in order to obtain information on the level of practice among administrators in the implementation of School-MSEQ and finally seeking the relationship between School-MSEQ and technology leadership among administrators in HPS.

\section{Results}

Research respondents were from 85 administrators from 12 High Performing Schools all over the country. From the amount of respondents, 40 people $(47.1 \%)$ with high level management which consisted of principals and Senior Assistant Teachers and 45 people (52.9\%) with the status as middle managers which consisted of subjects senior teachers. These research respondents also have multiple level of administration level that could be categorize into three levels. There were 45 people $(52.9 \%)$ who have 1 to 5 years of administration experience(s), 24 people $(28.2 \%)$ have 6 to 10 years of administration experience and finally 16 people $(18.8 \%)$ have administration experience of 11 years and more.

\subsection{The Level of Technology Leadership Practice}

Table 1 displays the interpretation of mean scores of the level of practice of technology leadership among administrators in High Performing Schools. Based on the interpretation of mean scores, the detailed analysis of the overall level of technology leadership in schools is presented in Table 2. The overall dimensions of 
technology leadership consist of aspects such as vision and leadership; teaching and learning; professional practice and productivity; management support and operation; evaluation and assessment; issues of social, legal and ethical.

Table 1. Interpretation of mean scores of the level of practice of technology leadership among administrators in high performing schools

\begin{tabular}{ll}
\hline Mean Score & Interpretation of Mean Score \\
\hline $1.00-2.99$ & Low \\
$3.00-3.99$ & Moderate \\
$4.00-5.00$ & High \\
\hline
\end{tabular}

Table 2 shows the overall mean score for dimension of technology leadership is 3.934. The data showed that the level of technology leadership practice among administrators in HPS is implemented at moderate level. Based on the mean scores for each dimension of technology leadership, it was found that the level of practice of technology leadership among administrators in HPS was more focused on the dimension of teaching and learning as compared to other dimensions.

Table 2. Mean scores, standard deviation of overall dimensions of technology leadership

\begin{tabular}{llll}
\hline Dimension of Technology Leadership & $\begin{array}{l}\text { Mean } \\
\text { Score }\end{array}$ & SD & $\begin{array}{l}\text { Level of } \\
\text { Implementation }\end{array}$ \\
\hline Vision and Leadership & 3.954 & 0.853 & Moderate \\
Teaching and Learning & 4.119 & 0.698 & High \\
Professional Practice \& Productivity & 3.888 & 0.811 & Moderate \\
Support, Management \& Operations & 3.978 & 0.904 & Moderate \\
Assessment and Evaluation & 3.858 & 0.807 & Moderate \\
Social, Legal \& Ethical Issues & 3.840 & 0.938 & Moderate \\
\hline Overall & 3.934 & 0.754 & Moderate \\
\hline
\end{tabular}

\subsection{The Level of Practice of School-Malaysia Standard of Education Quality}

Table 3 displays the interpretation of mean scores of the level of practice of School-Malaysia Standard of Education Quality. Based on the interpretation of mean scores, the detailed analysis of the overall dimensions of School-MSQE is presented in Table 4. The overall dimension of School-MSEQ consists of leadership direction, organizational management, educational programme management and student outcomes.

Table 3. Interpretation of mean scores of the level of practice of school-Malaysia standard of education quality in high performing school

\begin{tabular}{ll}
\hline Mean Score & Interpretation of Mean Score \\
\hline 1.00 to 2.33 & Low \\
2.34 to 3.66 & Moderate \\
3.67 to 5.00 & High \\
\hline
\end{tabular}

Source: Jamil (2002).

Table 4 displays the overall mean scores for dimensions of School-MSEQ was 4.729. The data showed that the level of practice of School-MSEQ among administrators in HPS was implemented at high level. 
Table 4. Frequency, percentage and mean of overall dimensions of school-MSEQ

\begin{tabular}{llll}
\hline Dimension of School-MSQE & Mean Score & SD & $\begin{array}{l}\text { Level of } \\
\text { Implementation }\end{array}$ \\
\hline Leadership Direction & 4.698 & .425 & High \\
Organizational Management & 4.707 & .428 & High \\
Management of Educational Programmes & 4.691 & .404 & High \\
Student Outcomes & 4.818 & .321 & High \\
\hline Overall & 4.729 & .346 & High \\
\hline
\end{tabular}

\subsection{The Administration Experience}

Table 5 displays the analysis of one-way ANOVA of technology leadership of administrators in HPS in term of administration experience. The one-way ANOVA statistics in Table 5 showed that there were no significant difference between administration experiences of 1 to 5 years, 6 to 10 years and 11 years and more at significant level $\mathrm{p}<0.05$ in the score of technology leadership of administrators in which the value of $\mathrm{F}(\mathrm{df}=2.82$, $\mathrm{P}>0.05)=1.829$. The data found that there is no significant difference of technology leadership practice among administrators in term of administration experience. The result of ANOVA test showed that different administration experiences do not influence the practice of technology leadership among administrators in High Performing School.

Table 5. ANOVA technology leadership of administrators in HPS in term of administration experience

\begin{tabular}{llllll}
\hline Source & Total Square & Square Mean & Dk & F & Sig \\
\hline Between groups & 2.043 & 1.021 & 2 & 1.829 & .167 \\
Inter groups & 45.786 & .558 & 82 & & \\
\hline Total & 47.829 & & 84 & & \\
\hline
\end{tabular}

Significant at level $\mathrm{p}<0.05$.

\subsection{The Status Post Held}

Table 6 displays the results of t-Test on the administrators in HPS who self-evaluated on their administration leadership of technology leadership practice in term of post status held. The analysis of T-test in the table above showed that the mean score of administrators in high level management consisting of principals and Senior Teacher Assistants was $4.048(\mathrm{~N}=40, \mathrm{SP}=) .742)$ and the mean score of administrators with the status as middle managers consisting of Subject Senior Teachers was $3.0843(\mathrm{~N}=45, \mathrm{SP}+0.760)$. The difference of mean scores $(0.018)$ between both groups were small and this supported the results of T-test which showed that there was no significant difference, the value of $\mathrm{t}(\mathrm{dk}=83, \mathrm{p}>0.05)$ was 0.213 . Therefore, the null hypothesis was accepted. The result findings showed that there was no significant difference of practice of technology leadership among administrators in HPS among administrators with high-level management post consisting of principals and Senior Teacher Assistants and the administrators with middle managers post consisting of Subjects Senior Teachers in term of practice of technology leadership.

Table 6. T-test for technology leadership of administrators in term of status post held

\begin{tabular}{lllllll}
\hline Post Status & $\mathbf{N}$ & Mean Score & SP & Dk & T & Sig. \\
\hline High level Management & 40 & 4.048 & .742 & 83 & 1.254 & 0.213 \\
Middle Managers & 45 & 3.843 & .760 & & & \\
\hline
\end{tabular}

Significant at level $\mathrm{p}<0.05$. 


\subsection{The Relationship between the Practice of Technology Leadership and School-Malaysia Standard of Education Quality}

Table 7 showed the value of correlation coefficient $r=.649$. This means that the relationship between the technology leadership practice and the School-Malaysia Standard of Education Quality was at moderate level. The value of $p(.000)$ is smaller than the level of 0.05 . Therefore, the null hypothesis was not accepted. These research findings showed that there is a significant relationship between technology leadership practice among administrators in HPS and the practice of School-MSEQ.

Table 7. The Correlation between the technology leadership practice and school-Malaysia standard of education quality

\begin{tabular}{llll}
\hline & & Technology Leadership & School-MSQE \\
\hline Technology Leadership & Pearson Correlation & 1 & $.649^{* *}$ \\
& Sig. (2-tailed) & & \\
\hline School-MSQE & Pearson Correlation & $.649^{* *}$ & 1 \\
& Sig. (2-tailed) & .000 & \\
\hline
\end{tabular}

$\mathrm{N}=85$.

Significant at level $\mathrm{p}<0.05$.

\section{Discussion}

This study found that the level of technology leadership practice among administrators in HPS for overall dimensions of leadership technology was implemented at moderate level. The administrators in HPS gave more focus on the dimension of teaching and learning as compared to other dimensions. These research findings were similar to research findings by Sabariah and Rohani (2006), Gurr (2000) and Chan et al. (2006). Sabariah and Rohani (2006) in their study on the principals as change agent in technology integration found that a change from the aspect of technology influenced the level of principal leadership practice as change agent in order to succeed in computer innovation in teaching and learning. Gurr (2000) in his study on 21 principals in Australia on ICT effects found that principals are advanced ICT users. While Chan et al. (2006) stated that administrators were open-minded and supported the technology integration that promoted the teachers to work towards the ICT integration in their process of teaching and learning. Administrators were not necessary have to be the technology expert but it was sufficient that they showed some interests on what the teachers did to implement the technology.

This study also found that the School-MSEQ practices for all dimensions were implemented at high level. These research findings were similar with study by Mohd. Zainol (2006) found that the teachers' perceptions on principals who practice the high level of leadership behaviours on the implementation of School-MSEQ. The leadership behaviours practiced by principals will enhance the commitment among teachers towards their educational quality and the school goals of educational quality.

Next, in studying the difference of technology leadership practice among administrators in term of administration experience, this study found that there was no significant difference of technology leadership practice among administrators in term of administration experience in which the difference experiences did not influence the technology leadership practice among administrators of HPS. These research findings were different from the study by Rusnah (2007) who found that there was a difference in technology leadership practice in term of administrators post for these dimensions: vision and leadership; teaching and learning and professional practice and productivity. However, these research findings were similar to research conducted by Yu and Durrington (2006) towards the practice and ability in implementing the technology standard for school administrators who showed that there was no significant difference between senior administrators and novice administrators in order to fulfil the technology standard set by NETS-A (2002).

There was no significant difference between administrators with high management level consisting of principals and Senior Assistant Teachers and administrators with middle managers status consisting of Subject Senior Teachers in term of technology leadership practice. The research findings was similar to Tan (2001) who elaborated that principals as school head of executive officer would determine the success of innovation and as 
the main school leader, the principal should widen the roles as manager and leader by giving empowerment to Subject Senior Teachers in effort for ICT integration culture will become reality in schools. This research finding also supported Saharuddin (2002) who stated that principals as school leaders should have high skills in using ICT in management and administration and principal should collaborate with teachers to learn and master the technology skills so that they could become the role models among teachers.

Finally, the research findings showed that there was a relationship between the technology leadership practice and School-MSEQ. The relationship between the technology leadership practice and School-Malaysia Standard Education Quality was at moderate level with the value of correlation coefficient $r=.649$. This research finding supported the research findings of Murugan (2003), Noor (2003) and Telem (2003). The research findings by Noor (2003) examined the survey on the implementation of Standard High Education Quality Programme (SHEQP) in secondary schools and it was found that the regression analysis of $\mathrm{R}=.363$, which means that six variables in his study contributed to $36.3 \%$ towards the success of the implementation programme. Meanwhile, the work of Murugan (2003) showed that $65 \%$ from the respondents agreed that the use of ICT could increase the quality of school management. Telem (2003) found that the integration of information system in schools have contributed to the rising control ability of principals in school. Simultaneously, this also helped to prepare the latest and accurate reports when needed. This will increase the ability of the administrators to supervise, monitor and evaluate the achievement of students and teachers supervision. The integration of information system also contributes to the rising cooperation, teamwork and leadership in schools.

\subsection{Implications on Practice}

The research findings clearly indicate that administrators play important and pivotal roles in promoting technology in schools. Thus, it could be seen that the involvement of leaders in all the areas of technology leadership as listed by International Society for Technology in Education is very crucial in raising the standard of School-MSEQ. Principals and other school leaders should also focus in other dimensions of technology leadership. Apart from giving central focus on teaching and learning dimension, administrators should also give emphasis on vision and leadership, professional practice and productivity, management support and operation, evaluation and assessment and issues of ethical, social and legal. The administrators should also relate their implementation of technology leadership to the standard set by the Malaysia Ministry of Education, which is called the School-MSEQ in order to contribute to the quality of school effectiveness and improvements.

\subsection{Conclusions and Recommendations}

It can be concluded that all the administrators in HPS practise the technology leadership and it requires more efforts by the administrators in order to broaden the educational technology quality of school management in reaching the status of High Performing School. The practice of School-MSEQ by the administrators should be sustained at all times in order to promote these standards. Although most researchers and educators found that it is a challenge to integrate technology into instruction (Shieh et al., 2010), it is worth for the administrators to strongly continue to broaden the use of technology in the school because this will enhance the quality of education as emphasized in the School-MSEQ. Finally, these research findings were hoped to be used by the Ministry of Education in examining the relationship between the School-Malaysia Standard Quality Education towards technology leadership in schools all over Malaysia. This research could also be used in planning the internal continuing professional development in order to increase the level of leadership among school administrators.

\section{References}

Anderson, R. E., \& Dexter, S. (2005). School technology leadership: An empirical investigation of prevalence and effect. Educational Administration Quarterly Journal, 40(1),49-82.

Avolio, B. J. (2000). Full Leadership Development: Building The Vital Forces In Organizations. London: Sage.

Baharom, M., Ahmad, E., Lian, A. F., Mohamad, H. M. H., \& Zurina, Y. (2007). Pengintegrasian pengurusan pengetahuan ke dalam sistem pengurusan teknologi maklumat dan komunikasi di IPT. UTOM national seminar proceedings JPPG 2007: Teknologi dalam pendidikan.

Bilig, S. H., Sherry, L., \& Havelock, B. (2005). Challenge 98: Sustaining the work of a regional technology integration initiative. British Journal of Educational Technology, 36(6), 987-1003.

Chan, L. J., Hong, J. C., Horn, J. S., Chang, S. H., \& Chu, H. C. (2006). Factors influencing technology integration in teaching a Taiwanese perspective. Innovations in Education and Training International, 43(1),57-68. 
Chang, M. (2005). The leadership ideas and strategies of learning school. Retrieved from http://www.edpl.tku.edu.tw/2-04.doc

Chien, Y., \& Durrington, V. A. (2006). Technology standard for school administrators: An analysis of practicing and aspiring administrators' perceived ability to perform the standards. NASSP Bulletin, 90(4), 301-317. Retrieved from http://www.eric.ed.gov/ERICWebPortal/Home

Creighton, T. (2003). The Principal as Technology Leader. California: Corwin Press, Inc.

Davies, P. M. (2010). On school educational technology leadership. Management in Education, 24(2),55-61.

Gurr, D. (2000). School principals and information and communication technology. Paper presented at Learning Conference. Melbourne, 6-9 July.

ISTE. (2002). National educational technology standards for administrators. Retrieved from http://cnets.iste.org/administartors/

Mohd, S. L. (2002). Perancangan Pendidikan Peringkat sekolah dan IPT. Kuala Lumpur: Utusan Publication Distributor Sdn. Bhd.

Mohd, Z. A. (2006). Kepimpinan pengetua dalam pelaksanaan SKPM di beberapa buah sekolah Negeri Selangor. Kuala Lumpur: Universiti Malaya.

Muhyiddin, Y. (2009). Teks ucapan majlis perasmian persidangan perkembangan baru dalam pendidikan 2010-2012. Pahang: Institut Aminuddin Baki.

Murugan A/L Ponnan @ Ponnapan. (2003). Aplikasi teknologi maklumat dalam pengurusan sekolah menengah di Daerah Lipis, Pahang. Kuala Lumpur: Universiti Malaya.

Noor, A. M. S. (2003). Tinjauan pelaksanaan program Standard Tinggi Kualiti Pendidikan (STKP) di sekolah menengah Daerah Rompin Pahang. Johor: Universiti Teknologi Malaysia.

Rashid. (2007). Teknologi maklumat dan komunikasi. Retrieved from http://www.scribd.com/doc

Rusnah, A. K. (2007). Pentadbir sebagai pemimpin teknologi: Kajian di sekolah-sekolah menengah di Negeri Sembilan. Bangi: Universiti Kebangsaan Malaysia.

Sabariah, S., \& Rohani, A. (2006). Kepimpinan pengetua sebagai agen perubahan dalam inovasikomputer dalam pengajaran dan pembelajaran. Konvesyen Teknologi Pendidikan ke-19, Jilid 2, 896-902.

Saharuddin, M. D. (2002). Penggunaan TMK (ICT) dalam pengurusan akademik di antara sekolah menengah dengan PPD. Kuala Lumpur: Universiti Malaya.

Shieh, R. S., Chang, W., \& Tang, J. (2010). The impact of implementing technology-enabled active learning (TEAl) in university physics in Taiwan. The Asia-Pacific Education Researcher, 19(3), 401-415.

Tan, S. Y. (2001). Peranan pengetua sekolah dan penggunaan komputer di sekolah sebagai satu inovasi: Satu kajian kes di Pulau Pinang. Jurnal pendidikan guru BPG.KPM, 14, 34-40.

Telem, M. (2003). Impact of school management information system on the principal's role. Progress in education. Nova Science Publication.

Zaharah. (2004). Persepsi guru-guru terhadap kesesuaian kriteria-kriteria untuk pembentukan standard/pengajaran. Johor: Universiti Teknologi Malaysia.

\section{Copyrights}

Copyright for this article is retained by the author(s), with first publication rights granted to the journal.

This is an open-access article distributed under the terms and conditions of the Creative Commons Attribution license (http://creativecommons.org/licenses/by/3.0/). 